\section{Deviances from planned purchases: consumer learning history and behavior setting implications for consumer spending}

\section{Marcos Inácio Severo de Almeida ${ }^{1}$ Ricardo Limongi França Coelho'}

${ }^{1}$ Federal University of Goiás (UFG), Faculty of Business Administration, Accounting Sciences and Economic (FACE), Goiânia, Brazil

\author{
Rafael Barreiros Porto ${ }^{2}$ \\ Denise Santos Oliveira ${ }^{2}$ \\ ${ }^{2}$ University of Brasilia (UnB), Business Management \\ Department, Brasilia, Brazil
}

\begin{abstract}
Purpose - Identifying the factors that influence consumer spending in retail has been a challenging topic for academics and marketing managers. Changes in consumption buying situations can encourage or discourage these expenses. We propose that deviations from planned purchases are specific classes of consumer behavior and can explain expenses.
\end{abstract}

Design/methodology/approach - The research project involved a field experiment in a supermarket where 372 purchases were observed for 13 weeks.

Findings - The results show the importance of both the learning history and the consumer scenario in forecasting deviations from planned purchases and the importance of these deviations in explaining expenses.

Originality/value - The results highlight that deviance groups are primarily responsible for spending more or less money on purchases, as well as the importance of consumer learning history and behavioral configuration in explaining behavior. This broadens the scope of the BPM, which often focuses on brand-level results.

Keywords - Behavioral Perspective Model, Consumer spending, Consumer learning history, Consumer behavior setting, Routine purchasing.
Recebimento:

$11 / 25 / 2018$

Aprovação:

$11 / 28 / 2019$

Editor responsável:

Prof. Dr. Helena Nobre

Avaliado pelo sistema:

Double Blind Review

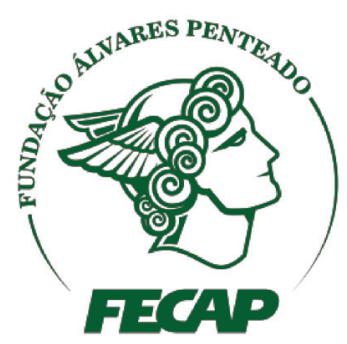

Revista Brasileira de Gestáo de Negócios 


\section{Introduction}

When a consumer enters a supermarket, they presumably have purchase goals regarding the categories they plan to buy from. That consumer can "fully match" the planned categories or exhibit deviances, which vary by different levels, ranging from minor deviations up to significant changes observed in actual behavior, representing different degrees of deviance from planned purchases. Consumer behavior as an investigation area usually combines all these degrees of deviance, describing them as unplanned purchases. Unplanned purchases occur in situations where the consumer buys at the point of purchase from a product category that was not included in their shopping list or their prior purchase intentions (Martínez-Ruiz, Blázquez-Resuno, \& Pino, 2017), possibly being motivated by an impulsive desire or simply by them recalling the need to purchase from the product category (Amos, Holmes, \& Keneson, 2014). These purchases contribute significantly to marketing results, such as increased retailer incremental profits, and have generated great interest from the academic community (Gilbride, Inman, \& Stilley, 2015).

Recent investigations have examined unplanned purchasing drivers based on economic, sociological, and cognitive psychology arguments (Xiao \& Nichonson, 2011). These studies investigate budget deviation (Stilley, Inman, \& Wakefield, 2010), unplanned purchasing drivers (Mohan, Sivakumaran, \& Sharma, 2013), and the results of unplanned purchases in retail, however they do not consider the existence of different degrees of deviance from planned purchases, nor an integrative analysis of unplanned buying behavior. Thus, questions that are relevant for a better understanding of unplanned purchases remain unanswered, such as whether consumers generally have high or low levels of deviations? What factors drive major or minor deviations? The main implication is that the literature overemphasizes unplanned purchases as being derived from consumers' susceptibility to in-store stimuli (Akyuz, 2018; Pornpitakpan, Yuan, \& Han, 2017; Memon, Kazi, Zubedi, \& Ansari, 2019; Stilley et al., 2010), while other classes of consumer behavior are neglected. What is the impact of major and minor deviations on current behavior, measured by consumer spending?

Behavioral and verbal protocols can be used to observe the degrees of deviations in purchases. As for the factors that drive larger or smaller deviations, operant theory behavioral studies perform an integrative analysis of consumer behavior based on the three-term analysis: stimulus, response, consequence. These behavioral studies have identified that in addition to store stimuli, that is, a present variable, intention-buy deviations are strengthened or weakened by paradoxical effects of past behavior (Sheeran, Godin, Conner, \& Germain, 2017). A base model of the operant theory of consumer behavior was proposed by Foxall (1992, 2015, 2017), the Behavioral Perspective Model (BPM). According to the BPM, the consumer's learning history with the product or buying environment acts as a stimulus for displaying future behaviors (Foxall, 1992, 2015, 2017).

The BPM has produced relevant empirical results, mostly at the brand level, stressing the importance of reinforcements to brand choice (Oliveira-Castro, Cavalcanti, \& Foxall, 2016; Porto \& Oliveira-Castro, 2013). An open avenue derived from this approach relates to the influence of consumer situational elements on actual-behavioral measures (Katona, 1974). Morales, Amir, and Lee (2017) emphasize the importance of actual-behavioral measures to improve research reliability. One barely researched measure of behavior is consumer spending, according to a historical analysis conducted by Wang, Bendle, Mai, and Cotte (2015), although it is a critical variable to the consumption phenomenon. Identified empirical research has analyzed spending at a micro-level for forecasting consumer spending (Carroll, Fuhrer, \& Wilcox, 1994; Carruth \& Dickerson, 2003; Fornell, Rust, \& Dekimpe, 2010), and at 
a transactional level, by breaking down spending into measures such as wallet sharing or wallet size (Jang, Prasad, \& Ratchford, 2016). To analyze whether major and minor deviations from planned purchases influence the measure of actual behavior, consumer spending makes sense since consumers are "situated" in a behavioral scenario composed of social and physical stimuli, where the primary product is chosen via a product or brand (Foxall, 2005) and, consequently for spending, a punishment is produced by the shopping environment (Oliveira-Castro et al., 2016).

Thus, the purpose of this article is to understand the behavior of unplanned purchases in the retail environment from the integrative view of the BPM. More specifically, it aims to: a) understand how consumers can be organized into groups that reflect their buying patterns after being observed in a real retail environment; b) verify the effect of variables of the consumer's learning history and the consumption scenario on groups of deviations in planned purchases; c) verify the effect of these groups of deviations in planned purchases on a substantial measure of performance and behavior at the individual level: consumer spending. The underlying importance of spending is that retail managers adapt their strategies when they note that consumer spending is declining, adjusting prices or assortment compositions (Fornell et al., 2010).

\section{Theoretical Background}

\section{I Unplanned purchases}

Purchases previously unplanned in a shopping list or according to pre-purchase declarations are known as unplanned purchases. They consist of purchase decisions made within the store (Martínez-Ruiz et al., 2017). According to Gilbride et al. (2015), unplanned purchases account for a significant portion of the retail market's financial results. Thus, a keen interest of managers and researchers has been to identify drivers of unplanned decisions within the store.
Research suggests that these purchasing decisions are driven by characteristics of the consumer (Iyer, 1989); geographical stimuli, such as the geographic region, which can change purchases from unplanned categories; social stimuli, such as the presence of third parties in the purchasing environment (Chomvilailuk \& Butcher, 2014); and especially inside store stimuli, such as customer exposure to discounted prices (Akyuz, 2018; Iyer, 1989; Pornpitakpan et al., 2017; Stilley et al., 2010). These stimuli can lead to a strong impulsive buying urge, known in the literature as impulse buying, or a simple reminder of the need to buy from a product category. Both are included in the context of unplanned purchases (Amos et al., 2014).

Although the studies developed present significant advances to understand unplanned purchasing behavior, the purchasing motivators pointed out by the literature are diverse and fragmented. An integrative analysis of this behavior can be performed through an economicbehavioral analysis (Xiao \& Nichonson, 2011). In an economic-behavioral analysis, unplanned buying behavior can be understood on the basis of a threefold contingency: stimuli > response $>$ consequences. Unplanned buying behavior is stimulated by elements of the current consumer behavior setting and the consumer's learning history. Further analysis of unplanned purchases based on economic and behavioral analysis is presented in the following section based on the Behavioral Perspective Model (BPM) proposed by Foxall (1992; 2017).

\section{I. I Using behavioral perspective elements to explain unplanned purchases}

The Behavioral Perspective of Purchase and Consumption Model (BPM) is a theoretical framework designed to investigate and interpret consumer behavior in complex marketing systems (Foxall, 1992). As shown in Figure 1, consumer behavior occurs at the intersection of two elements of the consumer situation, one from the present (consumer behavior setting, stimuli present in the buying scenario) and one from the past (learning history) (Foxall, 2017). 


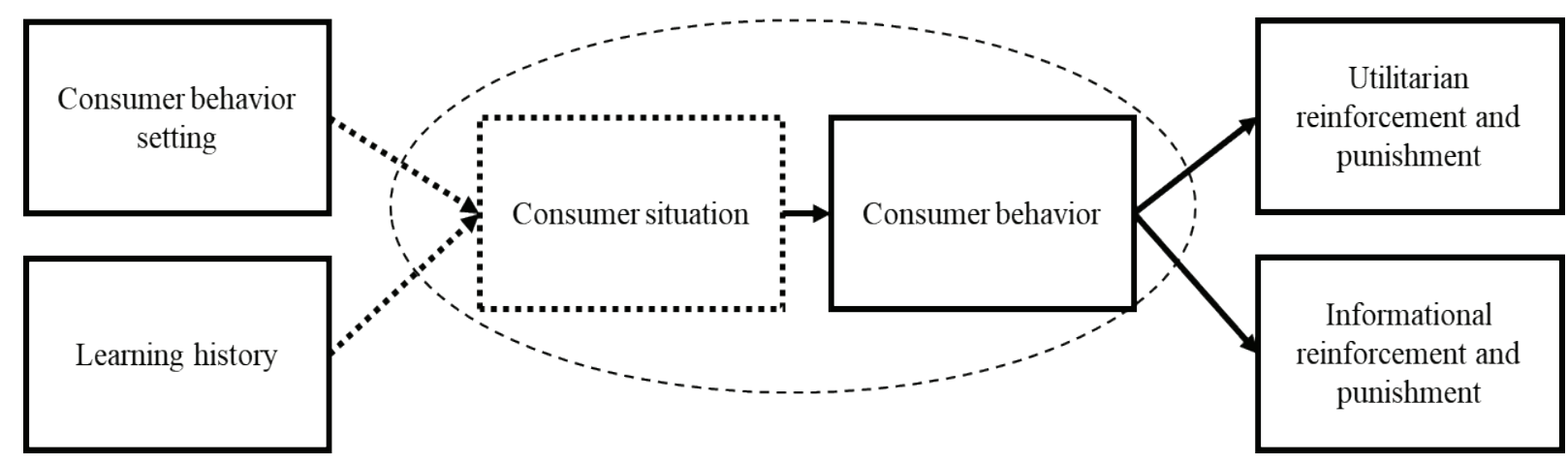

Figure 1. The Behavioral Perspective Model (BPM).

The section denoted by the dotted ellipse is the essence of the model. Dashed arrows indicate that the consumer behavior setting and learning history make up the consumer situation. The elements of the consumer situation stimulate consumer behavior, which in turn generates consequential utilitarian reinforcement/punishment or information reinforcement/punishment.

Source: Retrieved from "The Routledge companion to consumer behavior analysis" G. F. Foxall, "Consumer behavior analysis comes of age," 2016, pp. 3-21.

The stimuli present in the buying scenario can be physical (in-store advertising pieces), social (presence of sellers), temporal (store hours), and regulatory (prohibitive use of a helmet). The learning history, on the other hand, is based on the consumer's previous experiences with the store or product and adds meanings that will mediate their future behavior. The stimuli of the purchasing scenario, together with the learning history, will predict the consumer's future behavior (Foxall, 1998, 2017; Porto \& Oliveira-Castro, 2013). Based on this model, unplanned purchasing behavior will also be stimulated by consumer learning history variables and consumer scenario variables. In the present study, these variables are analyzed, and their effects on predictions of unplanned buying behavior are also examined.

Consumer behavior has consequences that may be utilitarian or informative, reinforcing or punitive. Utilitarian and/or informative consequences are programed into the purchasing environment and communicated to consumers through marketing mix actions. Utilitarian consequences derive from product use practices and consumer satisfaction or dissatisfaction responses to functional aspects of the product, such as smell, taste, texture, and cleanliness. Usage information is usually mentioned on the packaging or in the name or product campaigns. Information related to third-party feedback, or social reaffirmation, is usually linked to brands with a high level of prestige and social reliability. The possession of products with a high level of informative reinforcement will present social reinforcement and an increase of prestige, achievement, or respect (Oliveira-Castro, Foxall, $\&$ Wells, 2010). Such consequences will regulate the rate of occurrence of a behavior in similar future situations (Foxall, Oliveira-Castro, \& Schrezenmaier, 2007; Foxall, 2010; Sigurdsson, Kahamseh, Gunnarsson, Larsen, \& Foxall, 2013). Reinforcing consequences increase the likelihood of future repetition of a behavior, while punitive consequences reduce that probability (Foxall, 1992, 1998, 2010).

The configuration in which the behavior occurs may stimulate or inhibit the consumer response. Open purchase configurations are characterized by the freedom of the consumer in the buying scenario. For example, inside a bar or mall there are a variety of allowed behaviors, like choosing different types of products, watching a show, talking with other people, and entering and leaving the premises at any time. Thus, the consumer feels free to perform behaviors. In contrast, closed purchase configurations limit 
the behavior of the consumer. For example, when waiting in line at a bank there is no alternative if the consumer does not wait their turn, and they cannot enter or leave the line at will (Foxall, 1993, 2017). For example, in an open behavior setting, such as a supermarket, where functional and social benefits are low, individuals exhibit a specific class of behavior, i.e. maintenance, guided by routine purchasing (Foxall \& Yani-de-Soriano, 2005). However, even this routine may be susceptible to various dynamics, including in-store behaviors.

\subsubsection{Using behavioral perspective elements to explain consumer spending as an actual behavioral measure of unplanned purchases}

Consumer spending is an actual behavioral measure (Morales et al., 2017). Major and minor deviations from unplanned purchases can be reflected in this real variable. Foxall's (1998, p. 322) definition of consumer behavior includes "activities of buyers, former buyers, and potential buyers from prepurchase to post-purchase, consumption to discontinuance," but it overlooks this primary component of complex behavior, which arises in-store, where individuals use the environment as a cue to decide what to buy (Sigurdsson, Larsen, \& Fagerstrøm, 2016).

When analyzed at the individual level, consumer spending is a measure that reflects realistic behavior that has some form of consequence that signals consumer punishment (Oliveira-Castro et al., 2016). The "degree" of punishment may vary, as individuals may buy less or more than originally planned, circumscribing this behavior as deviating from a prescribed goal (Moschis \& Cox, 1989). This study investigates the effect of groups of deviations in planned purchases on this actual behavior variable, i.e. consumer spending.

\section{I.3 Framework proposal}

Therefore, our research model uses the BPM as a basis for understanding unplanned purchasing behavior in the retail environment. Considering an open configuration, such as a supermarket, consumer behavior results from behavioral configuration (present) and learning history (past), but also produces an important output that predicts actual consumer spending: deviations from planned purchases. Figure 2 shows our proposal.

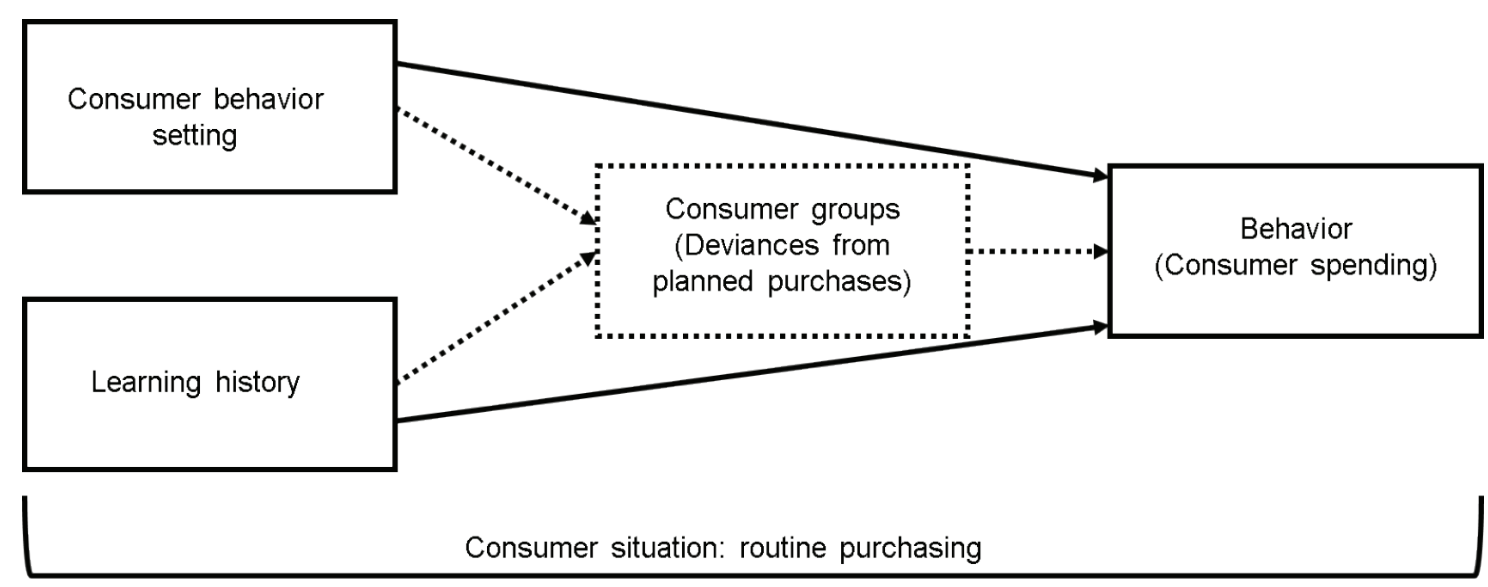

Figure 2. Research framework of consumer spending behavior in routine purchasing

Note. Solid arrows illustrate the influences on consumer behavior expected by the Behavioral Perspective Model (BPM) (and formalized by the extant literature), while dashed arrows incorporate our new proposed component: consumer groups, represented by deviances from planned purchases.

Source: From "Deviances from planned purchase: Consumer learning history and behaviour setting implications to consumer spending," M. I. S. Almeida, R. B. Porto, \& R. L. F. Coelho, 2016, p. 4 


\section{Method}

We organized a field experiment in a supermarket located in a Brazilian city in the central region of the country, with an estimated population of approximately 1.5 million inhabitants, according to the latest survey conducted by the Brazilian Institute of Geography and Statistics (IBGE). The chosen supermarket is open every day, has a total area of 8500 square meters, and includes meat, fresh produce, bakery, and beverage sections. The most frequent age distribution in the urban area of this city is between 30 and 39 years (223,816 individuals). This age group includes 107,713 men and 116,797 women (Instituto Brasileiro de Geografia e Estatistica, 2010; 2015). The supermarket is located in a central area, near the two main universities of this city and an expressway, which ensures sample randomization and variability.

We dedicated the first two weeks of the experiment to pretesting techniques. First, the survey instrument underwent expert review analyses before we decided on the final version. Members of a marketing research group conducted an interviewer debriefing with the researchers responsible for collecting data and scrutinized question wording and questionnaire structure. Subsequently, ten individuals were interviewed preliminarily to analyze their purchases during a field test (and eventually discarded), to assess problematic questions in the * survey instrument, and the best way to approach the respondent.

Over the following 13 weeks, we collected daily marketing variables present in the consumer scenario, such as whether the supermarket had any promotion for a specific product category (meat, fruit, or vegetables) on that day, and we invited customers of the supermarket during weekdays and weekends to participate in the research. The criterion used to select consumers was their intention to purchase something as they arrived in-store. Three trained researchers asked permission for a brief interview (Stage 1), where basic demographic and purchase plan information was collected. In the case of demographic variables, information was collected related to the latest IBGE census characteristics, such as household income, gender, and age. The behavioral variables were recorded by orally identifying whether the respondent had a shopping list or had consulted prices before arriving at the supermarket.

Seven questions were assessed: 1) which product categories the individuals were planning to buy from (38 category options, presented in separately; these variables were selected after an evaluation in a group of similar supermarkets, which are: Bar soap; Bean; Beer; Breads; Butter; Cheese; Chocolate; Chocolate milk; Coffeel Cookies; Deodorant; Detergents; Disinfectant; Fabric softeners; Flour; Fruits; Juice; Margarine; Meat; Milk; Moisturizer; Oils; Pasta in general; Rice; Sanitary water; Sauces; Seasonings; Shampoo; Soap; Soda; Sugar; Tea; Toilet paper; Toothpaste; Vegetables; Washing powder; Water; Yogurt); 2) if the consumer had a shopping list; 3) if they had carried out a previous price consultation; 4) reported household income (10 possible values, according to the IBGE); 5) gender; 6) age; and finally (7) if the individual was accompanied during that shopping trip. At the end of this brief interview, the researchers asked the consumers to provide them with the receipt after their payment at the counter (Stage 2). If a given respondent did not authorize this request, the completed questionnaire was automatically discarded. Given the information from Stage 1 and Stage 2, the researchers could compile and compare, after receiving the receipts, purchase plan and actual behavior information, such as the form of payment and the total value of the purchase. Accordingly, additional variables were registered, such as the day of the month, the day of the week, and promotion days (dummy variable) at the supermarket.

After the conclusion of the survey, Stage 3 started, where we developed a measure indicating consumer groups. This procedure involved a simple individual comparison between the number of categories the individual consumers planned to buy from and the quantity purchased from. This approach was inspired by a crossbuying measure developed by Kumar, George, and Pancras (2008). Although the participants were aware they were taking part in a research study (Morales et al., 2017), they did not know about this ex-post quasi-experimental manipulation. 
By comparing how many and which categories an individual bought from with how many and which categories they informed when they arrived at the supermarket, we were able to establish a set of consumer groups, based on degrees of deviance at the category level. For example, the first group refers to what we classify as the Effective Planned Purchase Group: individuals that fully match their purchases, buying only from planned categories. Conversely, the other groups include some form of deviance, in respect to matching planned categories and the amount (buying more or less) of categories bought from. The operational definitions of the consumer groups are shown in Table 1 along with basic descriptive statistics.

Table 1

Descriptive analysis of consumer groups

\begin{tabular}{|c|c|c|c|c|c|}
\hline Group name & Definition & $\mathbf{N}$ & $\begin{array}{l}\text { The incidence rate } \\
\text { in the sample }\end{array}$ & $\begin{array}{l}\text { Average of the } \\
\text { amount planned } \\
\text { (std. dev.) }\end{array}$ & $\begin{array}{l}\text { Average of the } \\
\text { amount bought } \\
\text { (std. dev.) }\end{array}$ \\
\hline $\begin{array}{l}\text { Effective Planned } \\
\text { Purchase Group }\end{array}$ & $\begin{array}{l}\text { Fully matched and purchased only } \\
\text { from the categories planned }\end{array}$ & 48 & $13.2 \%$ & $\begin{array}{l}1.85 \\
(1.2)\end{array}$ & $\begin{array}{l}1.85 \\
(1.2)\end{array}$ \\
\hline Deviance 1 & $\begin{array}{l}\text { Fully matched and purchased from } \\
\text { more categories than planned }\end{array}$ & 183 & $50.3 \%$ & $\begin{array}{l}2.49 \\
(1.9)\end{array}$ & $\begin{array}{l}6.11 \\
(4.6)\end{array}$ \\
\hline Deviance 2 & $\begin{array}{l}\text { Partially matched or unmatched } \\
\text { and purchased from more categories } \\
\text { than planned }\end{array}$ & 82 & $22.5 \%$ & $\begin{array}{l}5.26 \\
(3.9)\end{array}$ & $\begin{array}{l}9.64 \\
(6.3)\end{array}$ \\
\hline Deviance 3 & $\begin{array}{l}\text { Partially matched or unmatched } \\
\text { and purchased from fewer categories } \\
\text { than planned }\end{array}$ & 28 & $7.7 \%$ & $\begin{array}{l}5.85 \\
(5.2)\end{array}$ & $\begin{array}{c}3.5 \\
(3.7)\end{array}$ \\
\hline Deviance 4 & $\begin{array}{l}\text { Partially matched or unmatched and } \\
\text { purchased from the same number of } \\
\text { categories as planned }\end{array}$ & 23 & $6.3 \%$ & $\begin{array}{l}4.26 \\
(2.3)\end{array}$ & $\begin{array}{l}4.43 \\
(2.4)\end{array}$ \\
\hline Total & & 364 & $100 \%$ & $\begin{array}{l}3.40 \\
(3.1)\end{array}$ & $\begin{array}{l}6.04 \\
(5.2)\end{array}$ \\
\hline
\end{tabular}

The final sample comprised 372 observations (individual purchases). An a priori test, considering the number of groups and the number of covariates in the final model, using a medium effect size of 0.25 , a probability of error of $5 \%$, and a power of $95 \%$, returned a final sample of 364 individuals, which reveals a reasonably acceptable sample size for our field experiment.

\section{Results}

\section{I Descriptive characteristics of the sample}

Since one of the objectives of our study was to arrange consumers into groups relating to their buying patterns, the methodological approach employed organized the individuals into five possible outcomes. First, there are the ones that fully matched their initial intention and purchased only from the categories they planned to buy form, these individuals being classified as the Effective Planned Purchase Group. This group registered a $13.2 \%$ incidence rate, which is a low rate. The remaining $86.8 \%$ incidence rate belongs to four groups that deviated from their planned purchases, varying, in our proposal, according to two dimensions: a) if the individual matched (fully, partially, or not at all) their intention; and b) if the individual bought from more, less, or the same categories they planned to buy from.

Hence, our final categorization suggests four deviance groups: Deviance Group 1 fully matched and purchased from more categories 
than planned; Deviance Group 2 partially matched or did not match and purchased from more categories than planned; Deviance Group 3 partially matched or did not match and purchased from fewer categories than planned; and Deviance Group 4 partially matched or did not match and purchased from the same number of categories as planned. This construction includes minor deviations (Group 1) up to significant changes observed in actual behavior (from Group 2 to Group 4).

Table 2 presents the measurement approach used for the study variables, along with means and standard deviations. The consumers usually bought their products using cash $(51.1 \%)$ and debit cards (30.5\%), on non-promotion days $(67.6 \%)$ and on weekdays $(78.3 \%)$. These individuals were usually females $(65.4 \%)$, most with a reported household income ranging from U\$ 379 to U\$ 757 (28.7\%), whose shopping trips were not accompanied $(68.4 \%)$ and mostly unplanned, since only $16.8 \%$ brought a shopping list and $24.7 \%$ conducted a previous price consultation. Descriptive statistics for the quantitative variables show an average age of 40 and a mean purchase value of $U \$ 17$.

Table 2

\section{Descriptive analysis of the study variables}

\begin{tabular}{|c|c|c|c|}
\hline Variable & Measurement approach & Percentage & Mean (std. dev) \\
\hline Form of payment & $\begin{array}{l}\text { Qualitative } \\
\text { (three levels) }\end{array}$ & & \\
\hline $\begin{array}{l}\text { - In cash } \\
\text { - Debit card } \\
\text { - Credit card }\end{array}$ & $\begin{array}{l}51.7 \\
30.5 \\
17.8\end{array}$ & $\begin{array}{l}51.1 \% \\
30.2 \% \\
18.7 \%\end{array}$ & \\
\hline Reported household income & $\begin{array}{l}\text { Qualitative } \\
\text { (ten levels) }\end{array}$ & & \\
\hline $\begin{array}{l}\text { - up to U\$ } 156 \\
\text { - from U\$ } 157 \text { to } U \$ 379 \\
\text { - from U\$ } 380 \text { to } U \$ 758 \\
\text { - from } U \$ 759 \text { to } U \$ 1137 \\
\text { - from U\$ } 1138 \text { to } U \$ 1516 \\
\text { - from U\$ } 1517 \text { to } U \$ 1895 \\
\text { - from U\$ } 1896 \text { to } U \$ 2274 \\
\text { - from U\$ } 2275 \text { to } U \$ 2653 \\
\text { - from } U \$ 2654 \text { to } U \$ 3031 \\
\text { - more than } U \$ 3032\end{array}$ & $\begin{array}{c}3 \\
9.6 \\
28.7 \\
19.6 \\
9.8 \\
12.1 \\
7.2 \\
3.6 \\
1 \\
8\end{array}$ & $\begin{array}{c}0.3 \% \\
9.6 \% \\
29.1 \% \\
20.1 \% \\
9.9 \% \\
11.8 \% \\
6.9 \% \\
3.8 \% \\
0.8 \% \\
7.7 \%\end{array}$ & \\
\hline Promotion day at the supermarket & Dummy & $32.4 \%$ & \\
\hline Purchase during the weekend & Dummy & $21.7 \%$ & \\
\hline Gender (male) & Dummy & $35.4 \%$ & \\
\hline Consumer accompanied during the shopping trip & Dummy & $31.6 \%$ & \\
\hline Shopping list & Dummy & $16.8 \%$ & \\
\hline Previous price consultation & Dummy & $24.7 \%$ & \\
\hline Age & Quantitative $^{\mathrm{a}}$ & & $\begin{array}{c}40.04 \\
(15.76)\end{array}$ \\
\hline $\begin{array}{l}\text { Amount planned } \\
\text { (Number of categories registered during the } \\
\text { research interview (Stage 1)) }\end{array}$ & Quantitative & & $\begin{array}{c}3.4 \\
(3.1)\end{array}$ \\
\hline $\begin{array}{l}\text { Consumer spending } \\
\text { (Total value of the purchase) }\end{array}$ & Quantitative & & $\begin{array}{c}45.07 \\
(45.67)\end{array}$ \\
\hline
\end{tabular}

Note. ${ }^{a}$ The quantitative variables (age, amount planned, and consumer spending) underwent logarithmic transformation before inclusion in the inferential analyses to produce a scale-free interpretation.

Source: Retrieved from "Deviances from planned purchase: consumer learning history and behaviour setting implications to consumer spending,” M. I. S. Almeida, R. B. Porto, \& R. L. F. Coelho, 2016, p. 8. 
The inferential results are reported in the next two topics. Initially, we show the effect of the independent variables on the probability of belonging to groups other than the Effective Planned Purchase Group, using multinomial logistic regression. The use of this technique contributed to the evaluation of the five deviations collected (dependent variables) and the effects of the independent variables on the probability of occurrence (Clogg, Petkova, \& Haritou, 1995; Krishnapuram, Carin, \& Figueiredo, 2005) of the purchase plan, as in the study by Kumar et al. (2008).

Next, we unveil the effect of the deviance groups on consumer spending using an ANCOVA, which is used to evaluate if the dependent variable is equal across different levels of the independent variable (Akritas \& Van Keilegom, 2001). Overall, we show the set of variables that reflect influences of the past and the present on deviances from the effective purchase plan and what the potential "risks" are of spending more or less money, in comparison to a "planned" purchase.

\subsection{Influences on the probability of belonging to deviance groups}

We apply the multinomial logistic regression model technique to assess influences on the probability of belonging to deviance groups. The reference category for this case is the Effective Planned Purchase Group, who are individuals who matched their initial intention when arriving at the supermarket. We observe a low-moderate effect of independent variables on the chances of belonging to each group. The chi-square test of the model is significant ( $\mathrm{p} \leq 0.01)$, returning a Nagelkerke $\mathrm{R}^{2}$ of $35.4 \%$. Table 3 shows estimates (and standard errors) of the variables for each comparison of the deviance groups with the Effective Planned Purchase Group.

Table 3

\section{Effect of the independent variables on the probability of belonging to the deviance groups}

\begin{tabular}{|c|c|c|c|}
\hline Dependent variable $^{a}$ & Independent variables & Estimate & Std. error \\
\hline $\begin{array}{l}\text { Deviance } 1 \\
\text { (fully matched and purchased from more } \\
\text { categories than planned) }\end{array}$ & $\begin{array}{l}\text { Intercept } \\
\text { Previous price consultation } \\
\text { Shopping list } \\
\text { Consumer accompanied } \\
\text { Form of payment } \\
\text { Weekend } \\
\text { Log of the amount planned }\end{array}$ & $\begin{array}{c}0.91^{* * *} \\
0.83^{*} \\
-1.02^{* *} \\
0.96^{* *} \\
0.45^{*} \\
-0.97^{* * *} \\
0.43 \\
\end{array}$ & $\begin{array}{l}0.31 \\
0.48 \\
0.48 \\
0.46 \\
0.27 \\
0.38 \\
0.31 \\
\end{array}$ \\
\hline $\begin{array}{l}\text { Deviance } 2 \\
\text { (partially matched or unmatched and purchased } \\
\text { from more categories than planned) }\end{array}$ & $\begin{array}{l}\text { Intercept } \\
\text { Previous price consultation } \\
\text { Shopping list } \\
\text { Consumer accompanied } \\
\text { Form of payment } \\
\text { Weekend } \\
\text { Log of amount planned }\end{array}$ & $\begin{array}{c}-1.24^{* * *} \\
0.41 \\
-1.16^{* *} \\
0.87^{*} \\
0.39 \\
-1.46^{* * *} \\
2.01^{* * *} \\
\end{array}$ & $\begin{array}{l}0.41 \\
0.55 \\
0.58 \\
0.52 \\
0.30 \\
0.50 \\
0.36\end{array}$ \\
\hline $\begin{array}{l}\text { Deviance } 3 \\
\text { (partially matched or unmatched and purchased } \\
\text { from fewer categories than planned) }\end{array}$ & $\begin{array}{l}\text { Intercept } \\
\text { Previous price consultation } \\
\text { Shopping list } \\
\text { Consumer accompanied } \\
\text { Form of payment } \\
\text { Weekend } \\
\text { Log of Amount planned }\end{array}$ & $\begin{array}{c}-2.78^{* * *} \\
0.36 \\
-0.54 \\
0.78 \\
-0.70 \\
-0.34 \\
2.37^{* * *} \\
\end{array}$ & $\begin{array}{l}0.60 \\
0.70 \\
0.69 \\
0.64 \\
0.39 \\
0.58 \\
0.45\end{array}$ \\
\hline $\begin{array}{l}\text { Deviance } 4 \\
\text { (partially matched or unmatched and purchased } \\
\text { from the same number of categories as planned) }\end{array}$ & $\begin{array}{l}\text { Intercept } \\
\text { Previous price consultation } \\
\text { Shopping list } \\
\text { Consumer accompanied } \\
\text { Form of payment } \\
\text { Weekend } \\
\text { Log of amount planned }\end{array}$ & $\begin{array}{c}-2.47^{* * *} \\
0.43 \\
0.21 \\
0.33 \\
-0.29 \\
-0.96 \\
2.18^{* * *}\end{array}$ & $\begin{array}{l}0.61 \\
0.69 \\
0.66 \\
0.69 \\
0.42 \\
0.68 \\
0.47\end{array}$ \\
\hline
\end{tabular}

Nagelkerke $\mathrm{R}^{2}=35.4 \%$; chi square $=144.9(\mathrm{p} \leq 0.01)$

Note. Reference category: Effective Planned Purchase Group 
The consumer learning history (previous price consultation, consumer accompanied during shop) and behavior setting (form of payment - payment by credit card) variables exhibited a positive effect on Deviance Group 1, while purchasing during weekends and bringing a shopping list to the supermarket showed a negative effect. These results indicate that payment by credit card, being accompanied by someone, and previously consulting prices stimulate consumers to buy more products than planned, even though they fully matched the purchases (following the definition of Deviance Group 1).

By using the logistic probability formula $\left[\mathrm{P}(\mathrm{X})=1 / 1+\mathrm{e}^{-(\alpha+\Sigma \beta \mathrm{X})}\right]$, for example, if a consumer consults the planned product price before going to the supermarket, brings a shopping list to it, comes with someone, and pays using a credit card during the weekend, the probability of belonging to Deviance Group 1 is up to $83.3 \%$ in relation to the Effective Planned Purchase Group. These results show a significant effect of consumer learning history on changes in planned behavior.

Purchases during the weekend and bringing a shopping list to the supermarket provide self-control to the consumer and, also, have a negative effect on Deviance Group 2. Conversely, the amount planned has a positive effect on Deviance Group 2, Deviance Group 3, and Deviance Group 4. This means that the more products a given consumer plans to buy, the more they partially match or do not match their purchases, notwithstanding the amount bought.

Consumers being accompanied while shopping also had a small positive effect on Deviance Group 2. Therefore, consumers' companions stimulates them to buy more products than planned, even though the consumer can match the purchases or not. Applying the example in the logistic probability formula, in relation to the Effective Planned Purchase Group, if a consumer raises the number of products they plan to buy by $1 \%$, the probability of belonging to Deviance Group 3 or Deviance Group 4 is $39.89 \%$ and $42.80 \%$, respectively. In turn, if the consumer raises the amount they plan to buy by $1 \%$, purchases during a weekend, and brings a shopping list to the supermarket, the probability of belonging to Deviance Group 2 reaches $27.28 \%$.

\subsection{Influences on consumer spending}

Just as we tested whether there were any predictors of the deviances from the Effective Planned Purchase Group, in this analysis we are interested in observing a possible implication for these deviances in in-store consumer behavior, in an open routine purchasing setting (supermarket), which is consumer spending. Using an ANCOVA, we tested in which deviance groups consumers have higher spending, controlling for other variables, namely: the amount planned, the form of payment, the consumer being accompanied, the day of the month, and income.

Table 4 shows that the model accounts for $53 \%$ of the eta squared, a reasonably acceptable but moderate impact. The variables do not interact with each other (interactions not shown in Table 4 for questions of space), which means that the variables, alone, are responsible for the variances in consumer spending. The most impactful variable in relation to consumer spending is the deviance groups (higher partial eta squared $=$ $27 \%)$. Amount planned $[\mathrm{F}(1,352)=120.46, \mathrm{p}$ $\leq 0.01]$, form of payment $[\mathrm{F}(1,352)=24.57, \mathrm{p} \leq$ $0.01]$, consumer accompanied $[\mathrm{F}(1,352)=9.12$, $\mathrm{p} \leq 0.01]$, day of the month $[\mathrm{F}(1,352)=6.11$, $\mathrm{p} \leq 0.01]$, and income $[\mathrm{F}(1,352)=4.88, \mathrm{p} \leq$ 0.05] also have influences on consumer spending, though they are slightly less important. These results suggest that the deviance groups are the main factor responsible for consumers spending more or less money on purchases. 
Table 4

Effect of the deviances groups and control variables on consumer spending

\begin{tabular}{|c|c|c|c|c|c|}
\hline Source & Type III Sum of Squares & df & Mean Square & $\mathbf{F}$ & Eta Squared \\
\hline Corrected model & 223,37 & 9 & 24,82 & $35,50^{* * *}$ & 0,53 \\
\hline Intercept & 388,83 & 1 & 388,83 & $681,53^{* * *}$ & \\
\hline Deviance groups & 72,12 & 4 & 18,03 & $31,60^{* * *}$ & 0,27 \\
\hline Amount planned & 68,73 & 1 & 68,73 & $120,46^{* * *}$ & 0,26 \\
\hline Form of payment & 14,02 & 1 & 14,02 & $24,57^{* * *}$ & 0,07 \\
\hline Consumer accompanied & 5,21 & 1 & 5,21 & $9,12^{* * *}$ & 0,03 \\
\hline Ln day of the month & 3,49 & 1 & 3,49 & $6,11^{* *}$ & 0,02 \\
\hline Reported income & 2,78 & 1 & 2,78 & $4,88^{* * *}$ & 0,01 \\
\hline Error & 200,82 & 352 & 0,57 & & \\
\hline Total & 4401,57 & 362 & & & \\
\hline Corrected total & 424,19 & 361 & & & \\
\hline
\end{tabular}

Note. ${ }^{*} \mathrm{p} \leq 0.1 ;{ }^{* *} \mathrm{p} \leq 0.05 ;{ }^{* * *} \mathrm{p} \leq 0.01$. Once the control variables are entered as covariates, the relationship between each deviance group and consumer spending can be highlighted. Figure 2 shows that Deviance Group 1 (Mean = 3.55; S.E. $=0.1)$ and Deviance Group $2($ Mean = 3.52; S.E. $=0.1)$ have significantly $(\mathrm{p} \leq 0.01)$ more influence on Consumer Spending than the Effective Planned Purchase Group (Mean = 2.80; S.E. = 0.1). Deviance Group 3 (Mean = 2.35; S.E. = $0.2)$ has significantly $(\mathrm{p} \leq 0.01)$ less influence on Consumer Spending than the Effective Planned Purchase Group $($ Mean $=$ 2.80; S.E. = 0.1). The Effective Planned Purchase Group and Deviance Group $4($ Mean = 2.99; S.E. = 0.2) have moderate spending and they are not significantly different.

Source: Retrieved from "Deviances from planned purchase: consumer learning history and behaviour setting implications to consumer spending,” M. I. S. Almeida, R. B. Porto, \& R. L. F. Coelho, 2016, p. 11

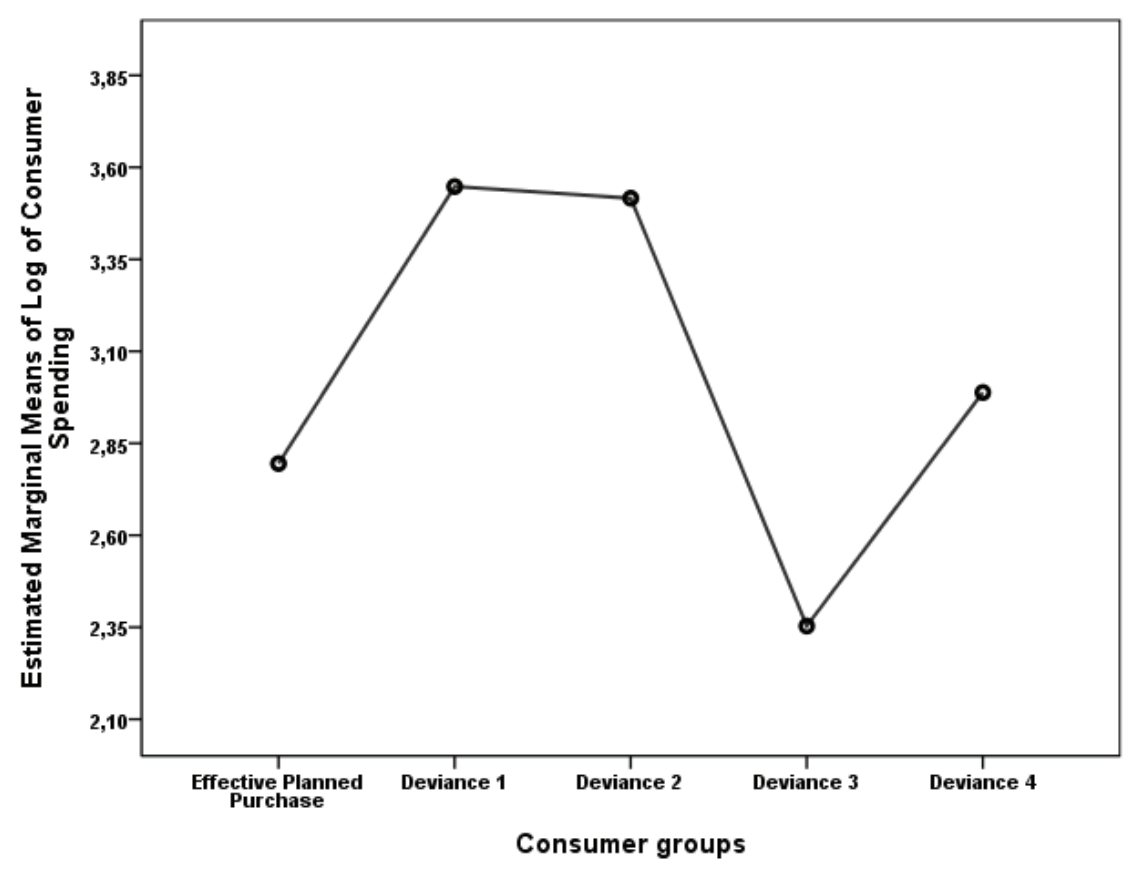

Figure 3. Estimated marginal means of consumer spending by deviance groups

Source: From "Deviances from planned purchase: Consumer learning history and behaviour setting implications to consumer spending," M. I. S. Almeida, R. B. Porto, \& R. L. F. Coelho, 2016, p. 11 
Overall, the logarithmic pattern of the impact of the covariates and deviance groups on consumer spending is shown in Figure 3. The illustration underscores a nonlinear pattern between the covariates and the main factor (consumer groups) and the response variable, consumer spending. The observations are randomly spread along the fitted line, revealing a fairly adequate fit between the model and the experimental data. Independent variables were chosen to moderately influence consumer spending $\left(\mathrm{R}^{2}=53 \%\right)$.

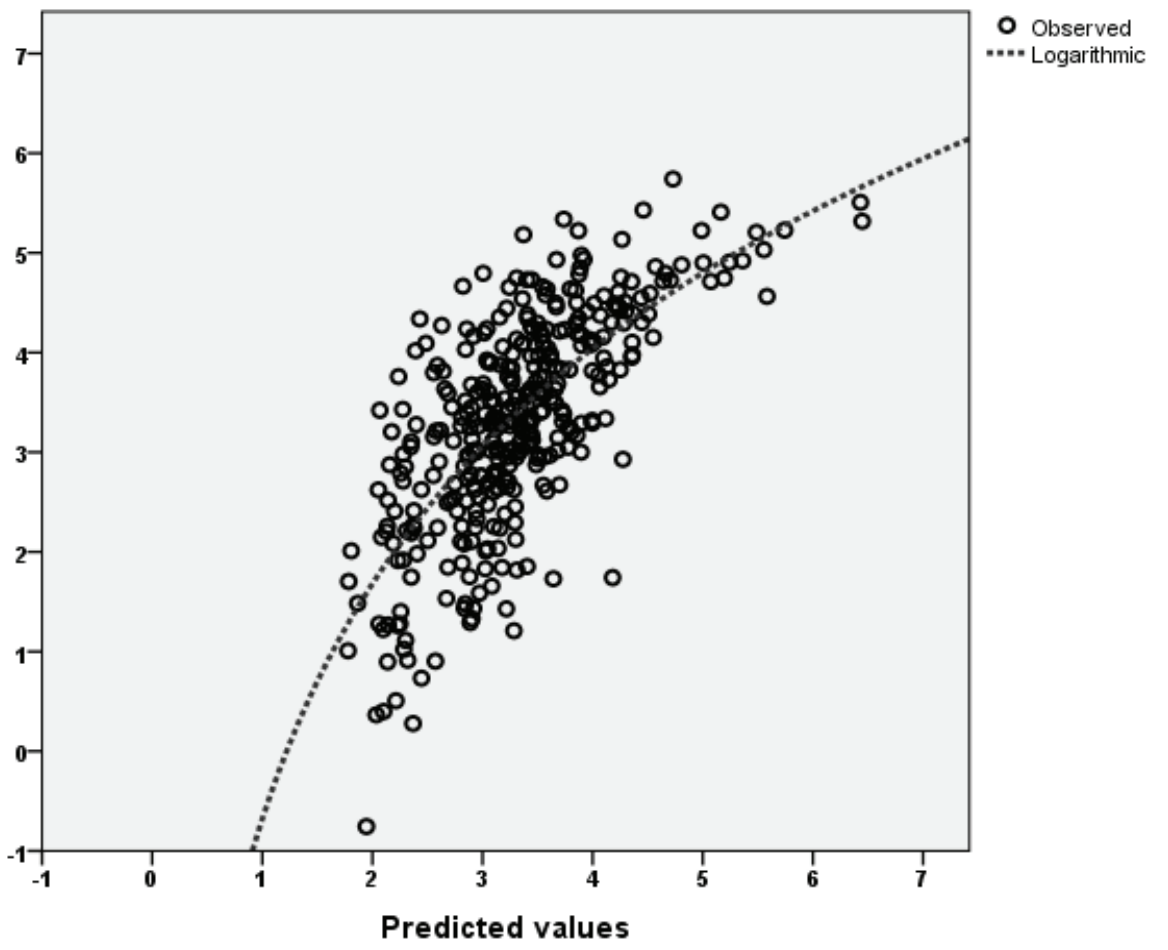

Figure 4. Impact of the covariates and deviances groups on consumer spending

Source: From "Deviances from planned purchase: Consumer learning history and behaviour setting implications to consumer spending,” M. I. S. Almeida, R. B. Porto, \& R. L. F. Coelho, 2016, p. 12.

\section{Discussion and Further Research}

Based on the assumption that deviances from planned purchases are specific classes of consumer behavior that may explain consumer spending, our empirical framework incorporates deviance as an important predictor of behavior in a context classified as an open routine purchasing setting. According to Foxall (2000), behavior is a function of the person's past experiences and the environment. This assumption guided the development of a framework which specified that consumer behavior is environmentally determined, but also under the control of individual learning history. The results of our multinomial model corroborate this premise, as price consultations and shopping lists can deviate consumers from the Effective Planned Purchase Group. This indicates an important effect of the pre-purchase component (the past) on behavior (the present).

Supermarkets are examples of open settings, where control mechanisms from marketers are largely absent. The resulting implication is that 
an unconscious behavior (Morales et al., 2017) can assist in the interpretation of punishment (spending) in a retail environment (OliveiraCastro et al., 2016). Considering the effects of the deviance groups on consumer spending and their substantial effect provided by the ANCOVA model, it is possible to formalize the consumer setting effect: in an open routine purchasing environment, consumers exhibit an in-store specific behavior, and organized deviances that may explain their "focal" behavior.

The results highlight that deviance groups are the main factors responsible for consumers spending more or less money on purchases, as well as the importance of consumer learning history and behavior setting to explain behavior. This expands the scope of the BPM, which usually focuses on results generated at the brand level. The consumer situation elements presented by Foxall (1992) and others (Oliveira-Castro et al., 2016) can also be related to an individual performance measure in retail, i.e. consumer spending. In practical terms, marketing managers involved with retail decisions can interpret these elements as internal and external factors responsible for producing effects on consumer expenditure.

Due to the nature of the experimental study, some limitations occur. One is the use of only one Brazilian city, limiting the understanding of behavior in different regions and sizes of supermarket. Another is the total period of the experiment, 13 weeks, which does not capture seasonal periods throughout the year. Moreover, the collection instrument, which uses a questionnaire to collect data, means respondents may have omitted purchase categories, and may also be influenced by new product purchases through contact with other customers, for example. Further research should incorporate these elements in different scopes of behavior setting as defined by Foxall (1992), such as accomplishment, pleasure, and accumulation environments.

\section{References}

Akyuz, A. (2018). Determinant factors influencing impulse buying behavior of Turkish customers in supermarket setting. International Journal of Research in Business and Social Science, 7(1), 1-10.

Akritas, M. G., \& van Keilegom, I. (2001). ANCOVA methods for heteroscedastic nonparametric regression models. Journal of the American Statistical Association, 96(453), 220.

Almeida, R. B., Porto, R. B., \& Coeliho, R. L. F. (2016). Deviances from planned purchase: Consumer learning history and behaviour setting implications to consumer spending. Anais do Congresso Latino-Americano de Varejo e Consumo - CLAV, São Paulo, Brasil, 9. Retrieved from http://bibliotecadigital.fgv.br/ocs/index.php/clav/ clav2016/paper/view/5813/1699

Amos, C., Holmes, G. R., \& Keneson, W. C. (2014). A meta-analysis of consumer impulse buying. Journal of Retailing and Consumer Services, 21(2), 86-97.

Carroll, C. D., Fuhrer, J. C., \& Wilcox, D. W. (1994). Does consumer sentiment forecast household spending? If so, why? The American Economic Review, 84(5), 1397-1408.

Carruth, A., \& Dickerson, A. (2003). An asymmetric error correction model of UK consumer spending. Applied Economics, 35(6), 619-630.

Chomvilailuk, R., \& Butcher, K. (2014). Social effects on unplanned in-store buying. ProcediaSocial and Behavioral Sciences, 148, 127-136.

Clogg, C. C., Petkova, E., \& Haritou, A. (1995). Statistical methods for comparing regression coefficients between models. American Journal of Sociology, 100(5), 1261-1293.

Fornell, C., Rust, R. T., \& Dekimpe, M. G. (2010). The effect of customer satisfaction on 
consume $r$ spending growth. Journal of Marketing Research, 47(1), 28-35.

Foxall, G. R. (1992). The behavioral perspective model of purchase and consumption: From consumer theory to marketing practice. Journal of the Academy of Marketing Science, 20(2), 189-198.

Foxall, G. R. (1993). A behaviourist perspective on purchase and consumption. European Journal of Marketing, 27(8), 7-16.

Foxall, G. R. (1998). Radical behaviorist interpretation: Generating and evaluating an account of consumer behavior. The Behavior Analyst, 21(2), 321-354.

Foxall, G. R. (2000). The contextual stance in consumer research. European Journal of Marketing, 34(7), 768-779.

Foxall, G. R. (2005). Understanding consumer choice. New York: Palgrave MacMillan.

Foxall, G. R., Oliveira-Castro, J. M, \& Schrezenmaier, T. C. (2007). The behavioral economics of consumer brand choice: Patterns of reinforcement and utility maximization. London: Palgrave Macmillan.

Foxall, G. R. (2010). Theoretical and conceptual advances in consumer behavior analysis: Invitation to consumer behavior analysis. Journal of Organizational Behavior Management, 30, $92-$ 109.

Foxall, G. R. (2015). Operant behavioral economics. Managerial and Decision Economics, 37(4-5), 215-223.

Foxall, G. R. (2016). Consumer behavior analysis comes of age. In G. F. Foxall (Ed), the routledge companion to consumer behavior analysis (pp. 3-21). New York: Routlege Companions.

Foxall, G. R. (2017). Advanced introduction to consumer behavior analysis. Cheltenham, UK: Edward Elgar Publishing.
Foxall, G. R., \& Yani-de-Soriano, M. M. (2005). Situational influences on consumers' attitudes and behavior. Journal of Business Research, 58(4), 518-525.

Gilbride, T. J., Inman, J. J., \& Stilley, K. M. (2015). The role of within-trip dynamics in unplanned versus planned purchase behavior. Journal of Marketing, 79(3), 57-73.

Instituto Brasileiro de Geografia e Estatística (2010). Brazilian census from 2010. Retrieved from http://censo2010.ibge.gov.br

Instituto Brasileiro de Geografia e Estatística (2015). Brazilian population estimation from July 1st, 2015. Retrieved from http://www.ibge.gov. br/home/estatistica/populacao/estimativa2015/ estimativa_tcu.shtm.

Iyer, E. S. (1989). Unplanned purchasing: Knowledge of shopping environment and. Journal of retailing, 65(1), 40.

Jang, S., Prasad, A., \& Ratchford, B. T. (2016). Consumer spending patterns across firms and categories: Application to the size- and shareof-wallet. International Journal of Research in Marketing, 33(1), 123-139.

Katona, G. (1974). Psychology and Consumer Economics. Journal of Consumer Research, 1(1), $1-8$.

Krishnapuram, B., Carin, L., Figueiredo, M. A. T., \& Hartemink, A. J. (2005). Sparse multinomial logistic regression: Fast algorithms and generalization bounds. IEEE Transactions on Pattern Analysis \& Machine Intelligence, 27(6), 957-968.

Kumar, V., George, M., \& Pancras, J. (2008). Crossbuying in retailing: Drivers and consequences. Journal of Retailing, 84(1), 15-27..

Martínez-Ruiz, M. P., Blázquez-Resino, J. J., \& Pino, G. (2017). Store attributes leading customer 
satisfaction with unplanned purchases. The Service Industries Journal, 37(5-6), 277-295.

Memon, R. H., Kazi, A. G., Zubedi, M. Y., \& Ansari, A. (2019). factors affecting impulse purchase behavior in hyderabad-marketing perspective. International Journal of Entrepreneurial Research, 2(1), 20-24.

Mohan, G., Sivakumaran, B., \& Sharma, P. (2013). Impact of store environment on impulse buying behavior. European Journal of marketing, 47(10), 8-8.

Morales, A. C., Amir, O., \& Lee, L. (2017). Keeping it real in experimental research Understanding when, where, and how to enhance realism and measure consumer behavior. Journal of Consumer Research, 44, 465-476.

Moschis, G. P., \& Cox, D. (1989). Deviant consumer behavior. Advances in Consumer Research, 16, 732-737.

Oliveira-Castro, J. M., Foxall, G. R., \& Wells, V. K. (2010). Consumer brand choice: Money allocation as a function of brand reinforcing attributes. Journal of Organizational Behavior Management, 3O(2), 161-175.

Oliveira-Castro, J. M., Cavalcanti, P. R., \& Foxall, G. R. (2016). What consumers maximize: Brand choice as a function of utilitarian and informational reinforcement. Managerial and Decision Economics, 37(4-5), 360-371.

Pornpitakpan, C., Yuan, Y., \& Han, J. H. (2017). The effect of salesperons' retail service quality and consumers' mood on impulse buying. Australasian Marketing Journal, 25(1), 2-11.
Porto, R. B., \& Oliveira-Castro, J. M. (2013). Preditores da correspondência intenção-compra: Experimento natural com reforço das marcas. Psicologia: Teoria e Pesquisa, 29(1), 61-70.

Sheeran, P., Godin, G., Conner, M., \& Germain, M. (2017). Paradoxical effects of experience: Past behavior both strengthens and weakens the intention-behavior rerlationship. Journal of the Association for Consumer Research, 2(3), 309-318. doi: $10.1086 / 691216$

Sigurdsson, V., Larsen, N. M., \& Fagerstrøm, A. (2016). Behavior analysis of in-store consumer behavior. In Foxall GR (Ed), The Routledge Companion to Consumer Behavior Analysis (pp. 40-50). New York: Routlege Companions.

Sigurdsson, V., Kahamseh, S., Gunnarsson, D., Larsen, N. M., \& Foxall, G. R. (2013). An econometric examination of the behavioral perspective model in the context of Norwegian retailing. The Psychological Record, 63(2), 277.

Stilley, K. M., Inman, J. J., \& Wakefield, K. L. (2010). Planning to make unplanned purchases? The role of in-store slack in budget deviation. Journal of Consumer Research, 37(2), 264-278.

Wang, X. S., Bendle, N. T., Mai, F., \& Cotte, J (2015). The Journal of Consumer Research at 40: A historical analysis. Journal of Consumer Research, 42(1), 5-18.

Xiao, S. H., \& Nicholson, M. (2011). Mapping impulse buying: A behaviour analysis framework for services marketing and consumer research. The Service Industries Journal, 31(15), 2515-2528. 


\section{Appendix 1 - Questionnaire applied to respondents at the supermarket entrance}

\section{Dear Customer,}

We are researching cross-buying across product categories. I want to request the completion of the following fields. They deal with some personal data, your purchase intention, and learning from the product categories offered at the supermarket.

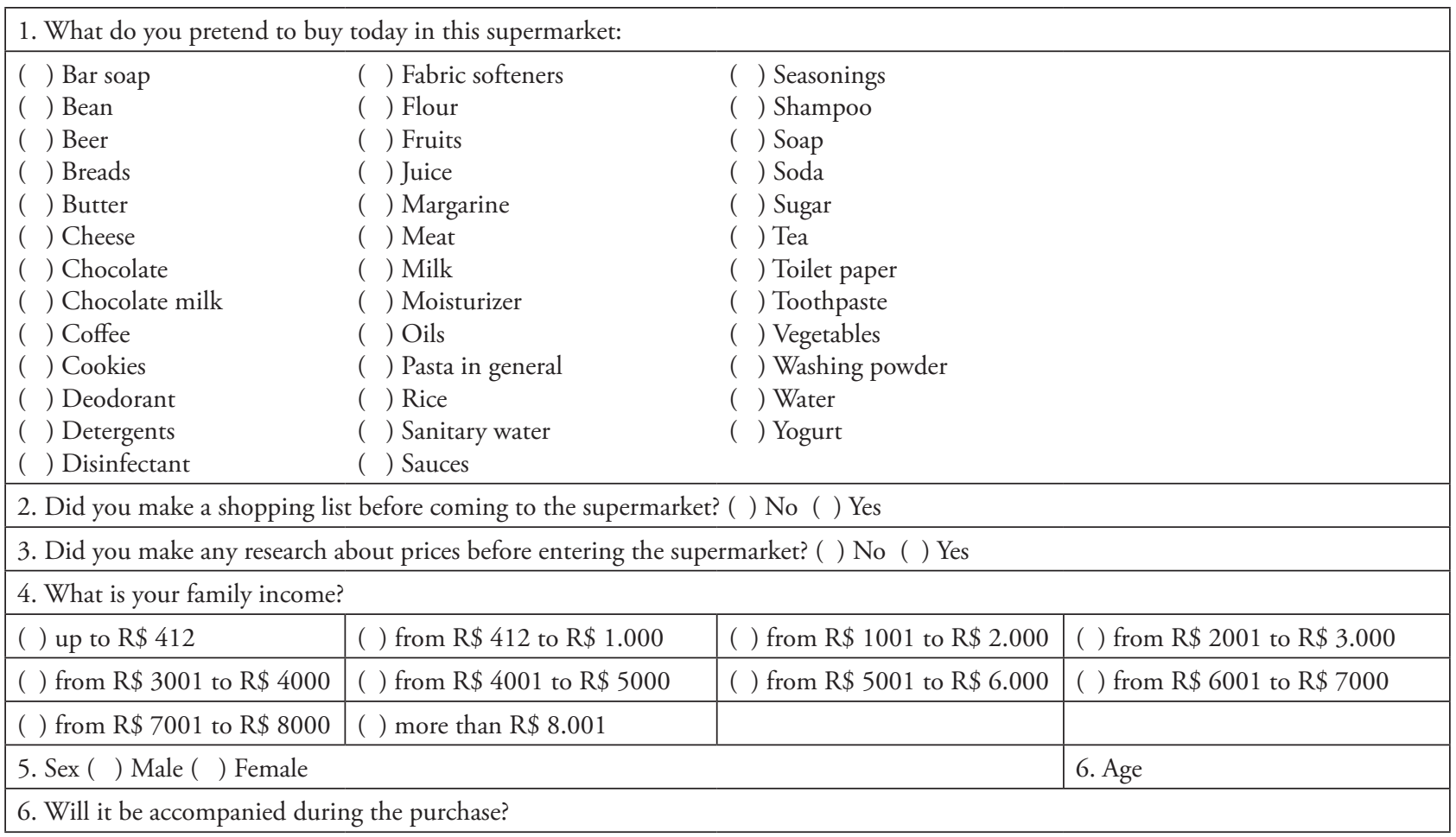


Authors:

1. Marcos Inácio Severo de Almeida, PhD in Business Administration, University of Brasilia, Brasília, Brazil. E-mail: misevero@yahoo.com.br

ORCID

(iD) 0000-0001-9493-0644

2. Ricardo Limongi França Coelho, PhD in Business Administration, Sao Paulo School of Business Administration at Getulio Vargas Foundation, Sao Paulo, Brazil.

E-mail: ricardolimongi@ufg.br

ORCID

(iD) 0000-0003-3231-7515

3. Rafael Barreiros Porto, Phd in Behavioral Sciences University of Brasilia, Brasília, Brazil.

E-mail: rbarreirosporto@gmail.com

ORCID

(iD) 0000-0003-2210-7098

4. Denise Santos Oliveira, Master's Degree in Business Administration, Federal University of Goias, Goiânia, Brazil. E-mail: deniseadm@hotmail.com

ORCID

(iD) 0000-0003-4981-119X

\section{Contribution of each author}

\begin{tabular}{|c|c|c|c|c|}
\hline Contribution & $\begin{array}{c}\text { Marcos } \\
\text { Almeida }\end{array}$ & $\begin{array}{c}\text { Ricardo } \\
\text { Coelho }\end{array}$ & $\begin{array}{c}\text { Rafael } \\
\text { Porto }\end{array}$ & $\begin{array}{c}\text { Denise } \\
\text { Oliveira }\end{array}$ \\
\hline 1. Definition of research problem & $\sqrt{ }$ & $\sqrt{ }$ & & \\
\hline 2. Development of hypotheses or research questions (empirical studies) & $\sqrt{ }$ & $\sqrt{ }$ & $\sqrt{ }$ & \\
\hline \multicolumn{5}{|l|}{ 3. Development of theoretical propositions (theoretical Work) } \\
\hline 4. Theoretical foundation/ Literature review & $\sqrt{ }$ & $\sqrt{ }$ & $\sqrt{ }$ & $\sqrt{ }$ \\
\hline 5. Definition of methodological procedures & $\sqrt{ }$ & $\sqrt{ }$ & $\sqrt{ }$ & \\
\hline 6. Data collection & $\sqrt{ }$ & $\sqrt{ }$ & $\sqrt{ }$ & $\sqrt{ }$ \\
\hline 7. Statistical analysis & $\sqrt{ }$ & $\sqrt{ }$ & $\sqrt{ }$ & \\
\hline 8. Analysis and interpretation of data & $\sqrt{ }$ & $\sqrt{ }$ & $\sqrt{ }$ & $\sqrt{ }$ \\
\hline 9. Critical revision of the manuscript & $\sqrt{ }$ & $\sqrt{ }$ & & $\sqrt{ }$ \\
\hline 10. Manuscript Writing & $\sqrt{ }$ & $\sqrt{ }$ & & $\sqrt{ }$ \\
\hline 11. Other (please specify which) & & & & \\
\hline
\end{tabular}

